\title{
Opinion Piece: A Call To Unite In A Common Cause
}

\author{
Chris Rust \\ Oxford Brookes University, UK
}

\section{Abstract}

This opinion piece argues that despite the successes of the Learning Development network, and the learning development community, separate development of this community may also have some dangers. It further argues that now is an auspicious time to try and bring about a paradigm shift in the attitudes of academic staff towards their role as teachers in higher education. Having presented the reasons why, it suggests that in order to increase the chances of bringing this about, the learning development and educational development communities should come together.

Keywords: change; graduate attributes; threshold concepts; research-based learning; assessment

As an educational developer for over twenty years, I have watched with interest the relatively recent, rapid and successful growth of the LDHEN. And while in some ways I think it is a shame that it was perceived necessary to set up a separate organisation for those involved in learning development, rather than feeling that there might already be a natural home within the educational development community in existing organisations like SEDA (Staff and Educational Development Association), I think I can also appreciate why it was. Apart from the obvious attraction of working just with people in the same sort of jobs and roles, with the same issues and problems and talking the same language, I am sure that a lot also has to do with the way institutions tend to separate the learning development role, its organisational location, the career structures, relative status, etc. And given the success of the LDHEN, I can see that when it comes 
to helping with those roles and the world of higher education as it exists now, it makes sense to have a separate, focused support network offering lots of practical ideas, developing communal resources and sharing good practice.

But looking to the future, I have two linked concerns. One is that this success may actually help to reinforce, and possibly perpetuate, the current, predominant remedial, 'sticking-plaster' view of learning development as an activity outside the curriculum that enables (and arguably even encourages) some academics to abdicate from feeling they have any responsibility to help those of their students who have problems with their learning. My second concern is about the separation of our two development communities. A successful, separate learning development provision may also, paradoxically, encourage some of the worst cost-cutting intentions of some of our institutional managers - the ability to provide support 'on the cheap' (through support staff rather than academic staff), and the further possibilities of deskilling the support that is actually provided with an increased (over) reliance by management on the (even cheaper) promise of e-learning, 'independent' learning etc. In short, the "Why don't you just develop some support packages and put them on the web?" scenario.

Now I assume that our two communities are united in a belief that learning development should not be a separate, central activity but, ideally, should be an integrated and indistinguishable part of course design and teaching/course delivery, with the course tutor responsible for the facilitation of the students' learning? I also believe that there has possibly never been a better time than now to bring about a paradigm shift in the attitudes of academic staff towards their role as teachers in higher education. And to increase our chances of bringing this about, I suggest it would be much better if we joined forces.

So what are the factors that make this such a potentially auspicious time. In no particular order, they are:

- Graduate attributes - stimulated by developments in Australia (see 
http://www.itl.usyd.edu.au/GraduateAttributes, and http://tinyurl.com/5q9t62), and it may possibly be, at least partially, a reaction by academics against the recent growth of the 'skills' lobby, but whatever the cause we have a new opportunity to get academics thinking about what are the particular graduate attributes they are developing in their discipline. Thinking about graduate attributes also has obvious potential links to the employability agenda and the question of what do graduate employers want in the $21^{\text {st }}$ century, which is currently of major concern to all of our institutions.

- Threshold concepts and troublesome knowledge - the recent work of Meyer and Land (2006) and Land, Meyer and Smith (2008) is stimulating growing interest because it seems to resonate with the experience of academics - and I know Ray Land spoke at the last LDHEN symposium. For those who were not there, and unfamiliar with the work, the thesis, in a nutshell, is that all disciplines have these 'threshold concepts' which can be likened to portals in that they are essential for progression in disciplinary understanding, and that are troublesome in nature, often requiring a significant change in the student's view of the discipline, and once achieved the change is probably irreversible. Although not the same, when planning a course programme, any discussion of either graduate attributes or threshold concepts in a given discipline would clearly benefit from discussion of the other at the same time.

- Research-based learning - the work of the Reinvention Centre, and some other CETLs, promoting a significant role for undergraduate research as part of the undergraduate curriculum, is stimulating a lot of interest and is starting to be implemented in a number of institutions. Research-based learning requires a very different view of course design, and also should lead to an inevitable change in the relationship between the lecturer and the student. No longer is the relationship one between the giver of knowledge (expert) and the receiver of knowledge (novice) but it becomes one of colleagues (albeit senior and junior colleagues) engaged in a joint enterprise. In addition, and linking to the other factors already discussed, research 
skills are clearly a major graduate attribute, and what better way of helping students grapple with threshold concepts than through getting them actively undertaking research in their discipline? (see www.warwick.ac.uk/go/reinvention and http://www.heacademy.ac.uk/assets/York/documents/LinkingTeachingAndResearch April07.pdf.

- Rethinking assessment - 2007 was the year that both the QAA and Burgess admitted that we have no adequate systems for ensuring standards, and that degree classifications are virtually meaningless. As part of a constructive response, the ASKe (Assessment Standards Knowledge exchange) CETL sponsored the production of an assessment manifesto, with an agenda for change (see http://www.business.brookes.ac.uk/learningandteaching/aske/Manifesto final.pdf). A significant thrust of that manifesto is that assessment practices need to focus more on assessment for learning (formative assessment) and the assessment of programme rather than module or unit outcomes. And programme outcomes should clearly relate to both threshold concepts and graduate attributes.

As I have tried to intimate, these ideas link well, and arguably even overlap. There really is the opportunity for a considerable amount of 'joined-up' thinking if these ideas can be discussed and implemented together, and even the possibility of a paradigm shift in the thinking of academics across the sector.

But where is the incentive for our academic colleagues to address these ideas? I believe there are two. The positive incentive is that, if presented well, these ideas can appeal intellectually to academic staff through their primary interest and allegiance to their discipline. The second, more negative but powerful incentive is the issue of competitiveness. With the declining demographic, and the possibility of the lid coming off fees, the competition for students is going to get increasingly fierce and important hence growing concerns over retention, recruitment, widening participation and the National Student Survey (NSS). Having both distinguishable positives - high employability, a discernibly special student experience - and eradicating negatives - 
reducing drop-out, moving up the NSS tables - are therefore going to be high on most Deans' agendas.

Now I acknowledge that probably nothing comes without also having a potential downside. To bring our two communities together may take some of us out of our comfort zone, may require some of our allegiances to loosen and be rebuilt, and may well require us to learn new skills. But these can all also be seen as opportunities, especially the potential benefit of learning from each other.

So, to summarise, it is my opinion that there has never been a better time to be both the catalyst of change and the provider of possible solutions, and I believe we will stand far more chance of achieving this if our two communities can come and work together. We therefore need to look for every opportunity, at both a local level, within our institutions, and nationally through our respective organisations, as well as the HEA and some of the CETLs, to work together - and promoting the paradigm shift identified above I believe is the cause around which we could and should unite.

\section{References}

Land, R., Meyer, J.H.F. \& Smith, J. (2008) Threshold Concepts within the Disciplines. Rotterdam and Taipei: Sense Publishers.

Meyer, J.H.F. \& Land R. (2006) Overcoming barriers to student understanding:

Threshold concepts and troublesome knowledge. RoutledgeFalmer.

\section{Author details}

Chris Rust is Head of the Oxford Centre for Staff and Learning Development, Oxford Brookes University 